\title{
A STUDY OF THE PRAIRIE FALCON IN SOUTHERN ALBERTA
}

\author{
by Barry F. Edwards, 6008 Bowwater Crescent N.W., Calgary
}

Because of the rapid decline in the Peregrine Falcon (Falco peregrinus) across most of North America in recent years, I decided to make a study of its close relative the Prairie Falcon ( $F$. mexicanus) during the summer of 1967 . In undertaking this study, I hoped first to establish that the population of the Prairie Falcon was in a more healthy state than the Peregrine, as had been suggested by the fact that John Campbell found 33 young in eight nests of this species on June 18 and 19, 1966, in southern Alberta, an average of over four young per nest (Calgary Bird Club Bulletin, 48:3).

This paper based on eight Prairie Falcon nest sites or eyries studied from April to August 1967, includes descriptions of each nest site, gives data on hatching and fledging success, and shows how the food taken varies as the season progresses and between pairs. Exact locations of these eyries have been omitted for security purposes.

I should like to acknowledge the assistance of Dr. M. T. Myres of the University of Calgary in planning the study and preparing this paper.

\section{METHODS}

The nests were marked with stakes requesting that they be left undisturbed, and subsequently none of the sites seemed to have been directly interfered with by human beings.

Nearly all visits had to be made in the evening, hence few traces of the species of prey fed upon in the morning remained. I kept the visits as short as possible while the birds were still incubating. As the eggs became further incubated the females became more aggressive and after the young hatched it seemed very unlikely that the birds would desert. The length of a visit has to be judged carefully especially since the temperament and sentitivity of different females varies.

\section{A. NEST SITES}

All eight nest sites were within a 25 -mile radius, but they do not represent the total population of that area since I checked only the most obviously suitable nest areas, i.e., cliff outcrops associated with rivers and creeks. Five sites were along a stretch of river, with the two farthest nests being about seven miles apart. All were on the north side of the river. The other three nest sites were in outcrops close to water, two overlooking creeks and the third beside a reservoir.

\section{Nest Site Descriptions}

Nest Site 1: A wind-eroded hollow in a sandstone cliff, 10 feet from the crest, 15 feet from the foot, with a long, siteep talus slope with clumps of vegetation. The birds had an uninterrupted view across the river valley.

Nest Site 2: (Fig. 1) A wind-eroded ledge on a sandstone cliff, 12 feet from the crest, 15 feet from the foot, with a short grassy talus slope. The birds had an uninterrupted view across the river valley.

Nest Site 3: A ledge at the back of a cave in a wind-eroded sandstone cliff, 7 feet from the crest, 10 feet from the foot with a short, gentle talus slope. The birds had no view of the area directly below the nest site.

Nest Site 4: (Fig. 2) A wind-eroded hollow of a sandstone cliff, 10 feet from the crest, 25 feet from the foot, with a short, steep, grassy talus slope. The birds had a clear view across the valley.

Nest Site 5: A wind-eroded hollow of a sandstone cliff, 7 feet from the crest, 10 feet from the foot, with a long, steep talus slope with clumps of vegetation. The birds had a clear view across the valley.

Nest Site 6: A roofed wind-eroded ledge of a sandstone cliff overlooking a creek, 10 feet from the crest, 15 feet from the foot with a long, steep talus 


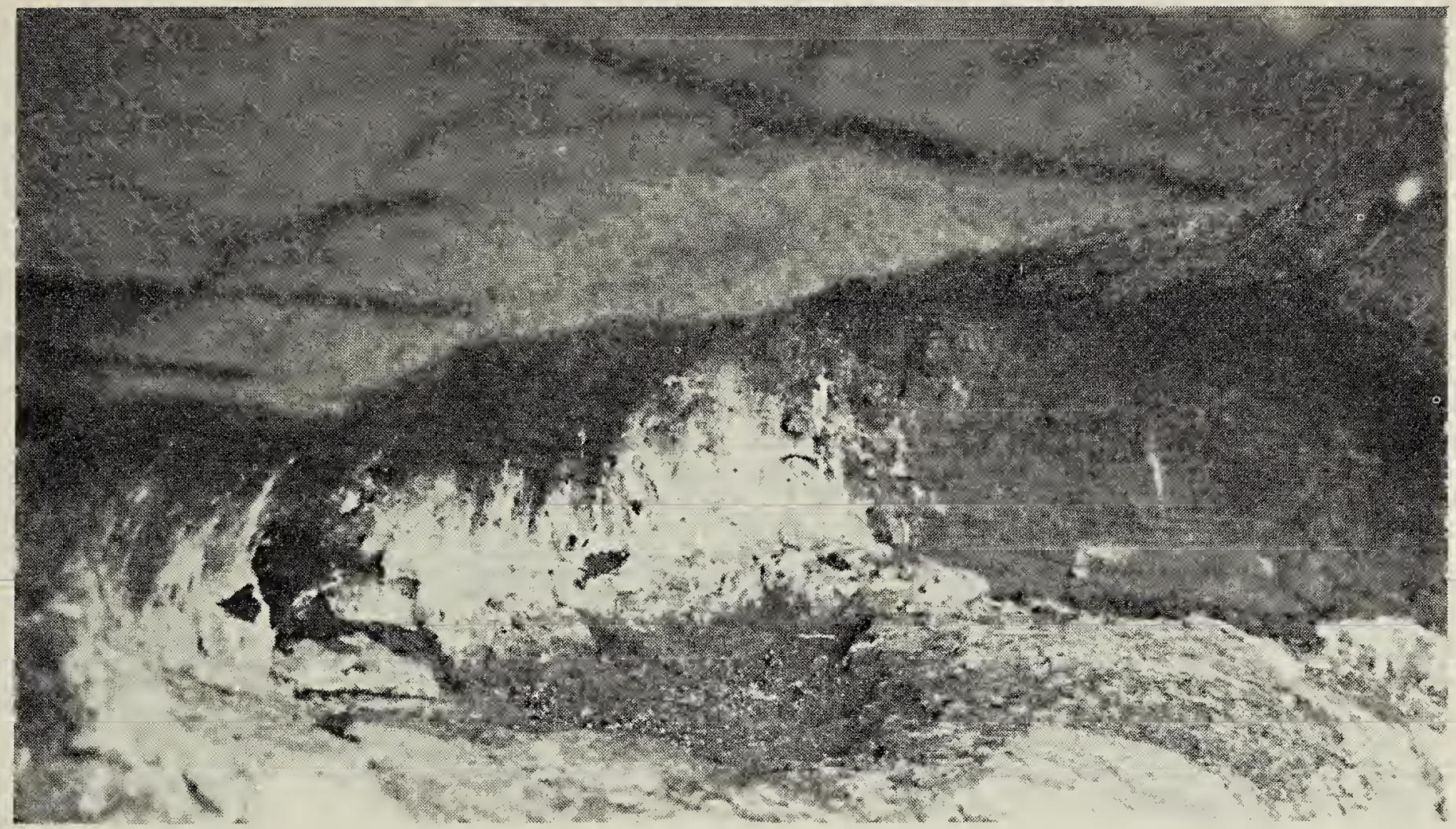

Fig. 1 - Nest site no. 2; a typical nest ledge.

slope. The birds had an uninterrupted view across the valley.

Nest Site 7: An open ledge of a sandstone cliff overlooking a creek, 8 feet from the crest, 15 feet from the foot, with a long talus slope. The birds had a view acrosis the valley.

Nest Site 8: A wind-eroded hollow of a sandstone cliff beside a reservoir, 5 feet from the crest, 30 feet from the foot, with a short, steep talus slope.

\section{Summary}

Five of the eyries were in winderoded hollows, two on covered ledges and one on an open ledge. Hollows posisibly provide downy young with better protection from aerial predators. Older young occupying hollows seemed to be more aggressive than young in other sites. All nest sites but one afforded the birds a clear view across the valley. The birds evidently (see Table 1) choose eyries as close to the top of the cliff as possible, presumbably to provide them with maximum protection from land predators and to give them a commanding view of the area below the site.

Nest sites 1 to 5 were in mixed farming and ranching areas with natural grassland above the tops of the cliffs. Nest sites 6,7 and 8 were in ranching country. The latter three sites raised seven young, an average of 2.3 young per nest, while the eyries in the mixed farming and ranching area raised seven young, an average of only 1.4 young per nest.

Human habitation did not seem to affect the falcons in their choice of nest sites: nesit site 7 was about 100 yards from a house, nest site 4 was about 200 yards from a farm house, and nest site 8 was about an eighth of a mile from a house.

\section{B. REPRODUCTIVE SUCCESS}

One or more eggs were removed from nests 1 to 5 on May 7 at the requesit of the Canadian Wildlife Service for analysis for pesticide residues (results not yet released).

Nest Site 1: Found with four eggrs on May 2. An egg was collected on May 7 leaving three eggs. On June 10 one young bird aged 3-4 days was in the nest with two unhatched eggs; these were collected. The one young bird was half grown on June 19 and it had left the nest when it was last seen on July 13. On August 13 no birds were seen at the site.

Nest Site 2: Found with five eggs on May 7; one egg was collected. On June 5 there were four young birds 2-3 days old. They were more than half 


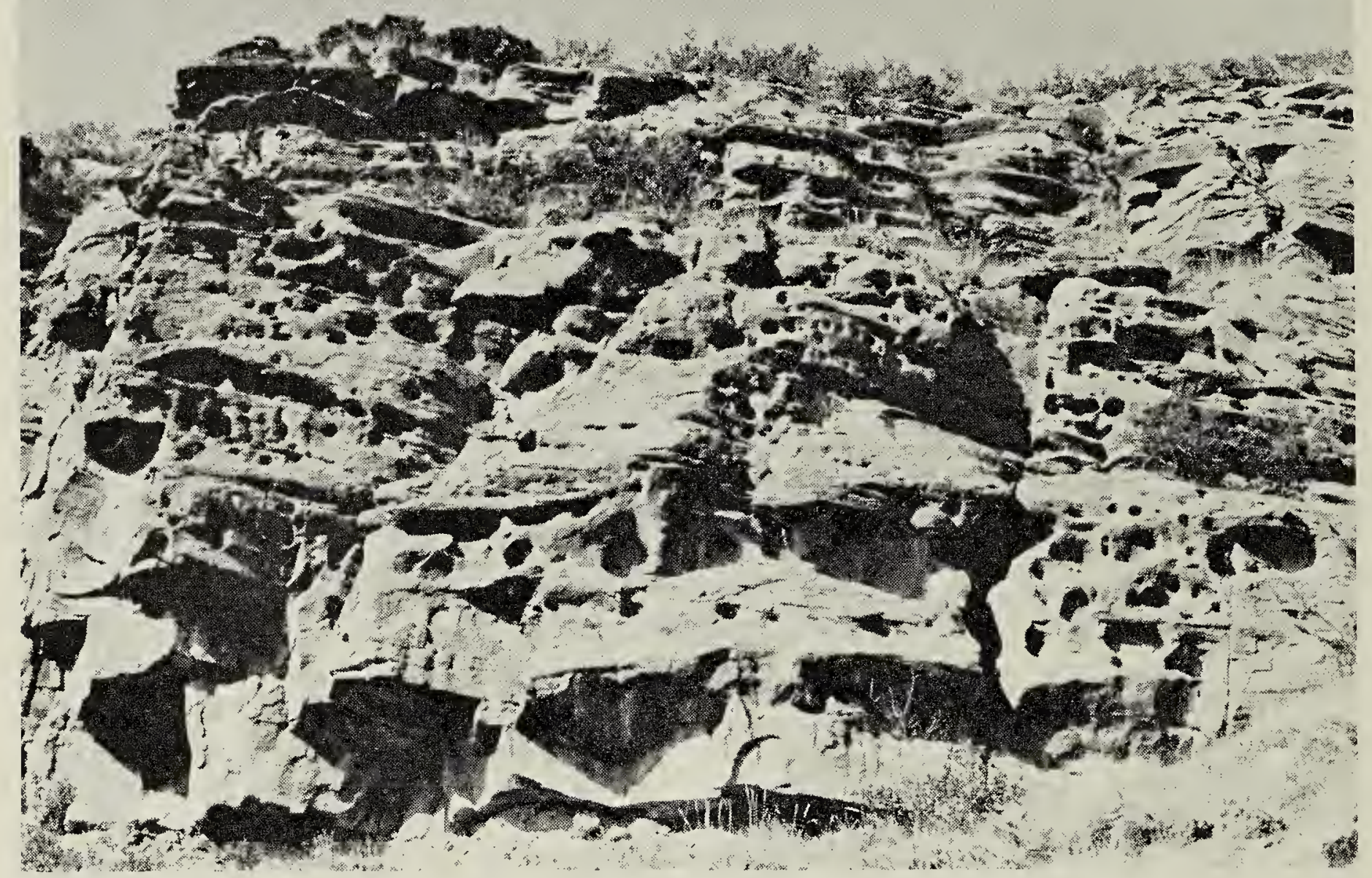

Fig. 2 - Nest site no. 4 ; the wind-eroded hollows preferred by Prairie Falcons.

grown on June 19 and were fully grown on June 29, when they were still on the nesting ledge. Two weeks later on July 14, three young birds were present and defended the area by stooping at the observer.

Nest Site 3: Found with five eggs on April 26. An egg was collected on May 7. On June 5 there were four young birds 2-3 days old. On June 21 only two, half-grown, young were seen. On July 13, two young birds were present with the parents, and the young birds joined with the adults in stooping at the observer. A month later on August 13, no birds were seen at the site.

Nest Site 4: Found with five eggs on April 26. An egg was collected on May 7 leaving four eggs. On May 20 there were only two eggs in the nest, and on June 5 only one egg remained; this was collected. This clutch was the only complete failure among the eight eyries.

Nest Site 5: Found with five eggs on
April 26. An egg was collected on May 7 , leaving four eggs. On June 12 there were four downy young in the nest. On June 29 these were half grown. On July 13 only one young bird was seen, and it was fully grown and flying. On August 13 no birds were seen at the site.

Nest Site 6: Found with four eggs on May 12. On June 11 there were four downy young in the nest. On June 20 the four young were quite aggressive. On July 2 two fully fledged young were seen. On August 13 there were no birds at the site.

Nest Site 7: Found with three young on June 20. These were fully grown and still on the nesting ledge. Five days later, on June 25 the three young birds were flying. Three weeks later on August 14, there were no birds at the site.

Nest Site 8: Found with two young on June 27, these birds were already flying. On August 14 there were no birds at the site. 


\section{Summary}

Six nests with clutches were found between April 26 and May 12. Of these, four had clutches of five eggs, and two had clutches of four eggs. The average clutch size was 4.7 .

In two nests eggs disappeared, apparently naturally, or failed to hatch. In Nest 1 two eggs did not hatch. In Nest 4 two eggs disappeared after one had already been collected and later a third egg disappeared. Since the nest was by then abandoned the last remaining egg was also collected. The loss of eggs in this nest either followed desertion caused by the initial visit of the observer, or was associated with the fact that there was no male observed at the site during any of the four visits.

The removal of an egg from each of the clutches of eggs rneant that in none of the nests studied was there ever more than four young, so it is not known if the parents would have been under duress if they had had to feed five young in 1967, which was a dry summer.

Hatching occurred in the last few days of May and the first 10 days of June. At Nest 2 hatching occurred about June 2-3, at Nest 1 it occurred about June 6-7, and at Nests 5 and 6 about June 9-11.

There seems to have been some natural losses of young from the nest. In Nest 3 only two of four young hatched reached the half-grown stage. In Nest 5 only one flying young was observed from four young present at the half-grown stage. In Nest 6 only two young became fully grown from four young present at the half-grown stage. Thus of 12 young hatched from 12 eggs, two young died before they were half-grown and up to five more apparently died after that stage, leaving a minimum of only five flying young from 12 eggs hatched. A further indication of poor fledging is indicated by the two nests found only after the young had hatched. These produced only five flying young, an average of 2.5 young per nest.

Young were full grown as early as June 20 (Nest 7) and were first observed flying on June 25 (Nest 7). Young were lasit seen in the nest on July 2 (Nest 6). Young birds were still defending the site by stooping as late as July 14 at more than one nest.

\section{FOOD}

Table 2 lists some of the prey species found in the nest. The nest site was cleared after each visit as far as passible so that the samples collected at the next visit would be reasonably new. In the short time I was at each nest I took fresh pellets, a sample of other pellets and any easily identifiable remains. The table does not, therefore, pretend to present a quantitative analysis, but it nevertheless shows the relative proportion of birds to mammals that were being used as food during each month of the breeding season.

\section{TABLE 1: RELATIVE POSITIONS OF THE EYRIES}

\begin{tabular}{cccc}
\hline Site No. & $\begin{array}{c}\text { Length of talus slope } \\
\text { below cliff foot* }\end{array}$ & $\begin{array}{c}\text { Height above } \\
\text { foot of cliff* }\end{array}$ & $\begin{array}{c}\text { Distance below } \\
\text { crest of cliff* }\end{array}$ \\
1 & 75 & 15 & 10 \\
2 & 35 & 15 & 12 \\
3 & 30 & 10 & 7 \\
4 & 25 & 25 & 10 \\
5 & 120 & 10 & 7 \\
6 & 300 & 15 & 8 \\
7 & 110 & 15 & 5 \\
8 & 30 & 30 & 8.6 \\
Average & 90.6 & 16.8 & \\
\hline
\end{tabular}

*Dimensions in feet 


\section{Nest}

BIRD

W. Meadowlark breast-

feathers

6 pellets (small birds)

Robin breast-feathers.

Gray Partridge breast-

feathers

sparrow (sp.?) primaries.. $26 \quad 5$

Clay-colored Sparrow

secondaries

Horned Lark secondaries

longspur (sp.?) wing and tail feathers

$26 \quad 5$

$26 \quad 5$

$26 \quad 5$

\begin{tabular}{|c|c|}
\hline & May \\
\hline sparrow (sp.?) prin & 2 \\
\hline $\begin{array}{l}\text { ongspur (sp.?) wing } \\
\text { feathers }\end{array}$ & 7 \\
\hline $\begin{array}{l}1 \text { pellet (medium-sized } \\
\text { bird) }\end{array}$ & \\
\hline pellets (small birds) & \\
\hline
\end{tabular}

June

Robin beak, foot and leg bone

3 pellets (sp.?)

sparrow primaries (sp.?)

1 pellet (sp.?)

Robin primaries

sparrow primaries (sp.?)..

pellets (bird sp.?) ........... 1

Magpie primaries ............. 12

primaries (small bird sp.?)

Horned Lark (wing coverts)

3 pellets (bird sp.?)

Robin remnants sparrow primaries (sp.?)..

Goldfinch 1 pellet

Franklin's Gull wing

ite

\section{MAMMAL}

April Site

3 pellets (field vole)

$26 \quad 3$

Fur (field vole)

264


Site 2 birds continued to be a major food item all through June. At Nest Site No. 1 the adults did not switch to ground squirrels at all. This pair seemed to have specialized in birds since no mammal remains were found at the nest. It is possible that the fact that two of their eggs did not hatch is related to this, but this will not be known until the eggs are analysed.

Why adult Prairie Falcons did not take ground squirrels more often for their own use in May is not clear, but it is interesting that they preferred to feed them to their young. (Some ground squirrel prey samples were also frozen for analysis).

\section{CONCLUSION}

This paper describes the position of eight Prairie Falcon eyries in southern Alberta in 1967, success of these nests, and the food remains found at the nest. Eyries were closer to the top of the wind-hollowed sandstone cliffs used, than to the bottom. Birds appeared to be the food favored by the

\section{EXPLORERS JOURNAL}

is a scientific and educational quarterly devoted to those scientific disciplines which are both the tools and purposes of the exploration of Earth and space.

"The explorer is the poet of action and exploring is the poetry of deeds."-Stefanssion

Canadian subscriptions: one year, $\$ 7.00$, two years, $\$ 12.00$, three yearis, $\$ 17.00$.

Editorial offices: 4500 Wetherill Road, W a'shington, D.C. 20016, USA. Business and subscription office: The Explorers Club, 46 East 70th Street, New York City, New York 10021 US.A. adults. After the eggs began to hatch ground squirrels became the predominant food item brought to the nest.

In 1966 an average of four young was found in eight eyries visited in the second half of June. In 1967 the fledging success was very much less than this. It is not though't that my visits to the nests played any part in reducing reproductive success since young flew successfully from seven of the eight nests studied. May and June of 1966 were wet months whereas in 1967 they were comparatively dry. Presumably this might be expected to bring about some differences in the food available to the Prairie Falcons in the two years. It is not known yet whether the eggs being laid by these pairs of Prairie Falcons contained appreciable quantities of pesticide residues. But it is of some interest that, at least in 1967, these birds (like Peregrine Falcons) were eating numbers of birds early in the breeding season. Whether there is any cause and effect relationship between the food eaten and the weather, or between the food eaten and poor survival of the young remains to be determined by comparative studies in ensuing years.

\section{PRAIRIE NEST RECORDS SCHEME}

Contributors are reminded to send 1968 nest record cards to Dr. Robert W. Nero, Prairie Nest Records Scheme, Manitoba Museum of Man and Nature, Winnipeg 2. If you have not previously contributed to the scheme but are interested in keeping records of individual nests or colonies of nests, write to Dr. Nero for information and nest record cards. 